\title{
KOMPARASI MODEL PEMBELAJARAAN KOOPERATIF TIPE MAKE A MATCH DAN TIPE TEAM GAMES TOURNAMENT (TGT) PADA MATERI KONSEP MOL TERHADAP HASIL BELAJAR SISWA KELAS X SMA KARTIKA XIII-1 AMBON
}

\author{
Marlifia Berhitu1, S. Unwakoly ${ }^{1 *}$, Y. Manoppo ${ }^{1}$ \\ ${ }^{1}$ Departement of Chemistry-FKIP, Pattimura University Ambon \\ *email: semuel.unwakoly@fkip.unpatti.ac.id
}

Diterima 10 September 2018/Disetujui 14 Oktober 2018

\begin{abstract}
The purpose of this research is to know thestudent learningoutcomes of grade X SMA KARTIKA XIII-1 AMBON as well as knowing there is a difference whether or not the results of student learning using cooperative type Team Games Tournament(TGT) with type Make a Match as the learning model. This research is the comparison research which the sample consists of two classes, the class was given further study of chemistry at the consept of moles materials, first classexperiment (X-1) using the cooperative type Team Games Tournament(TGT) and in secondclass experiment (X-2) using the cooperative type Make a Match as the learning model. Based on the results of the study gained note that both models of learning that can enhance the learning outcomes of students, it can be seen from the success of the qualifications obtained from both the class when there has same qualification of $75 \%$ of students are on completed qualifying, $25 \%$ of students are on failed qualifying, with average from X-1 class used Type TGT is 66.125 and X-2 class used Type Make a Match is 57.3125. Hypothesis test data derived from posttest both class indicates the value significance of $0.25(>0.05)$ this a value of $\mathrm{H}_{0}$ received and value of $\mathrm{H}_{1}$ rejected so it can be concluded there is no difference in student learning outcomes are either the cooperative type Team Games Tournament (TGT)and type Make a Match as the learning model.
\end{abstract}

Keywords: Model of Learning Cooperative Type Team Games Tournament (TGT), Cooperative Learning Model Type Make a Match, the Learning Outcomes.

\begin{abstract}
ABSTRAK
Telah dilakukan Penelitian komparasi model pembelajaran kooperatif tipe Make a Matchdan Team Games Tournement(TGT) pada Materi Konsep Mol terhadap hasil belajar siswa kelasX SMA KARTIKA XIII-1 AMBON. Model Pembelajaran Kooperatif tipe Team Games Tournament di terapkan pada kelas X-1 dan Model Pembelajaran Kooperatif tipe Make a Match di terapkan pada kelas X-2, pengolahaan data dilakukan dengan menggunakan Software SPSS 20. Penggunaan kedua Model Pembelajaran ini diketahui dapat meningkatkan hasil belajar siswa, dilihat dari presentase pencapaian hasil tes akhir yang diperoleh kedua kelas, di mana kedua kelas memiliki presentase kualifikasi hasil tes akhir yang sama yakni kualifikasi tuntas $75 \%$ siswa, sedangkan kualifikasi gagal $25 \%$, dengan nilai rata-rata untuk kelas X-1 yang menggunakan model pembelajaran kooperatif tipe Team Games Tournmaent (TGT)adalah 66.125 dan untuk kelas X-2 yang menggunakan model pembelajaran kooperatif tipe Make a Match adalah 57.3125 dan dari data hasil uji T dengan menggunakan SPSS 20 diperoleh nilai signifikansi sebesar 0.25 (>0.05). dengan demikian maka $\mathrm{H}_{0}$ diterima dan $\mathrm{H}_{1}$ ditolak sehingga dapat disimpulkan tidak terdapat perbedaan hasil belajar siswa menggunakan model pembelajaran kooperatif tipe Team Games Tournament(TGT) dan tipe Make a Match.
\end{abstract}

Kata kunci: Model Pembelajaran Kooperatif, Teams Games Tournement (TGT), Make a Match, Hasil Belajar. 


\section{PENDAHULUAN}

Dari hasil observasi yang dilakukan di SMA Kartika XIII-1 Ambon ditemukan bahwa pada konsep kimia secara keseluruhan, cara mengajar guru masih monoton dengan kata lain guru masih menggunakan metode ceramah yang bersifat satu arah sehingga siswa hanya melihat dan mendengar materi yang dijelaskan dan kemudian harus bisa mengerjakan tugas yang diberikan guru. $\mathrm{Hal}$ ini menyebabkan siswa terkesan pasif dalam proses pembelajaran, sulit untuk menerima dan terkadang siswa malas untuk mengikuti pelajaran di kelas. Berdasarkan masalah di atas dapat disimpulkan bahwa salah satu faktor penyebab rendahnya hasil belajar siswa adalah proses pembelajaran yang dilakukan oleh guru. Hal ini yang membuat sehingga penulis tertarik untuk menggunakan model pembelajaran kooperatif karena model pembelajaran ini yang proses pembelajarannya ada dalam kelompok belajar.

Dalam penelitian yang dilakukan oleh Dea, Y. P., dkk (2016: 3) menunjukan bahwa penerapan model pembelajaran tipe make a match pada materi konsep mol hasilnya lebih baik dari pada penerapan model pembelajaran tipe talking stick pada materi konsep mol. Yang dimana dari hasil penelitiannya menunjukkan bahwa pada kelas eksperiment I (Talking Stick) pada aspek kognitif, nilai terendah dari prestasi kognitif siswa adalah 2.95, nilai tertinggi 4.00, dan nilai rata-rata 3.38. sedangkan untuk kelas eksperiment II (Make a match) nilai terendah dari hasil kognitif siswa 2.78 , nilai tertinggi 4.00 , dan nilai rata-rata 3.58 .

Sedangkan dalam penelitian Anggraini, K. P., dkk (2015: 214) menunjukan bahwa penerapan model pembelajaran tipe teams games tournament lebih baik dibandingkan dengan model pembelajaran team assissted individualized pada materi konsep mol. Yang dimana dari hasil penelitiannya menunjukan bahwa pada kelas eksperiment I (TGT) pada aspek kognitif, nilai terendah dari prestasi belajar kompetensi pengetahuan siswa adalah 75 , nilai tertinggi 92 dan nilai ratarata 85,67. Sedangkan untuk kelas eksperimen II (TAI) nilai terendahnya adalah 65, nilai tertinggi 92 dan nilai rata-rata 82,56 .

Dari hasil penelitian yang telah dijelaskan di atas, menunjukan bahwa hasil belajar dari kedua model pembelajaran yakni model TGT dan Make a match adalah lebih baik dan efektif dibandingkan dengan model pembelajaran yang dikomparasikan. Untuk itulah, peneliti sangat tertarik untuk melakukan penelitian terkait komparasi kedua model pembelajaran tersebut terhadap materi kimia yang akan diteliti. Komparasi kedua model pembelajaran tersebut diteliti nantinya untuk melihat dari kedua model pembelajaran yang telah berhasil diterapkan ini manakah yang memiliki hasil belajar yang lebih maksimal.

Berdasarkan uraian di atas, maka penulis merasa perlu untuk menggunakan perbandingan hasil belajar siswa dengan menggunakan kedua model tersebut dalam penelitian dengan judul; "Komparasi Model Pembelajaraan Kooperatif Tipe Make A Match Dan Tipe Team Games Tournament (Tgt) Pada Materi Konsep Mol Terhadap Hasil Belajar Siswa Kelas X Sma Kartika XIII1 Ambon".

\section{METODE PENELITIAN}

\section{A. Tipe Penelitian}

Penelitian ini merupakan penelitian komparasi. Penelitian komparasi adalah penelitian yang membandingkan dua variabel atau lebih dengan tujuan mengetahui mana yang lebih baik dan melihat penyebabnya. (Sudijono 2006: 273).

Penelitian komparasi ini yaitu dengan membandingkan Model Pembelajran Kooperatif Tipe Make a Match dengan Tipe TGT (Teams Games Tournament). 


\section{B. Lokasi dan Waktu Penelitian}

1. Lokasi Penelitian

Penelitian ini dilaksanakan di SMA Kartika XIII-1 Ambon.

2. Waktu Penelitian

Penelitian dilaksanakan pada tanggal 24 Januari- 10 Februari 2018

\section{Populasi dan Sampel}

1. Populasi

Populasi penelitian adalah siswa kelas X SMA Kartika XIII-1 Ambon

2. Sampel

Sampel penelitian yakni kelas $\mathrm{X}-1$ yang akan diterapkan model pembelajaran kooperatif tipe TGT dan kelas X-2 yang akan diterapkan model pembelajaran kooperatif tipe Make a Match

3. Variabel Penelitian

Variabel yang digunakan dalam penelitian adalah Variabel Bebas dan Variabel terikat.

a. Variabel bebas

Variabel bebas dalam penelitian ini adalah: Model pembelajaran kooperatif tipe TGT untuk kelas Eksperimen I dan Model pembelajaran kooperatif tipe Make a Match untuk kelas Eksperimen II

b. Variabel terikat

Variabel terikat dalam penelitian ini adalah: Hasil belajar siswa

4. Instrumen Penelitian

Instrumen yang digunakan dalam penelitian ini adalah Test dan Non-test.

a. Instrumen test berupa tes awal dan tes akhir

b. Instrumen non- test berupa pengamatan afektif dan psikomotor

c. Kartu soal

5. Teknik Pengumpulan Data
a. Teknik Tes
b. Pengamatan atau Observasi
c. Kartu Soal

6. Teknik Analisis Data

a. Analisis Deskriptif

- Penilaian untuk tes awal dan tes akhir

Skor Pencapaian $=\frac{\text { skor perolehan }}{\text { skor } \text { maksimum }} \times 100$

- Penilaian selama proses Diperoleh dari nilai kartu soal yang digunakan pada model pembelajaran kooperatif tipe TGT dan Make a Match.

Skor Pencapaian Kartu Soal $=\frac{\text { skor perolehan }}{\text { skor maksimum }} \times 100$

- Penilaian aspek Afektif dan Psikomotor diperoleh dari rata-rata pencapaian RPP Pertemuan I, Pertemuan II dan Pertemuan III.

Skor Pencapaian $=\frac{\text { skor perolehan }}{\text { skor } \text { maksimum }} \times 100$ 
Tabel 1. Tingkat Penguasaan Kompetensi dan Kualifikasi

\begin{tabular}{|c|c|}
\hline Tingkat Penguasaan Kompetensi & Kualifikasi \\
\hline $90-100$ & Sangat Baik \\
$75-89$ & Baik \\
$60-74$ & Cukup \\
$<60$ & Gagal \\
\hline
\end{tabular}

KKM SMA Kartika XIII-1 Ambon

b. Uji Statistik

Uji beda terhadap data posttest dilakukan dengan menggunakan program SPSS 16.0, yaitu uji normalitas, uji varians, dan uji parametrik (uji t tidak berpasangan).

(1) Uji Normalitas

Jika sig $>\alpha(0,05)$, distribusi data normal

Jika sig $<\alpha(0,05)$, distribusi data tidak normal

(2) Uji Varians

Jika sig $>\alpha(0,05)$, maka $\mathrm{H}_{0}$ diterima

Jika sig < $\alpha(0,05)$, maka Hoditolak (Trihendradi, 2004:106)

Hipotesis:

$\mathrm{H}_{0}$ : Kelompok data posttest antara kelas eksperimen I dan kelas eksperimen II memiliki varian yang sama

$\mathrm{H}_{1}$ : Kelompok data posttest antara kelas eksperimen I dan kelas eksperimen II memiliki varian yang berbeda

(3) Uji parametrik (uji t tidak berpasangan)

Jika sig $>\alpha(0,05)$, maka tidak terdapat perbedaan antara kedua kelompok data posttest $\left(\mathrm{H}_{0}\right.$ diterima).

Jika sig $<\alpha(0,05)$, maka terdapat perbedaan antara kedua kelompok data posttest $\left(\mathrm{H}_{0}\right.$ ditolak) (Trihendradi, 2004:106)

\section{HASIL PENELITIAN}

\section{Tes Akhir}

Tabel 2. Kualifikasi Tes Akhir kelas TGT dam kelas Make a match

\begin{tabular}{|c|c|c|c|c|c|}
\hline \multirow{2}{*}{ Interval } & \multicolumn{4}{|c|}{ Frekuensi } & \multirow{2}{*}{ Kualifikasi } \\
\cline { 2 - 5 } & $\begin{array}{c}\text { Kelas } \\
\text { TGT }\end{array}$ & $\%$ & $\begin{array}{c}\text { Kelas } \\
\text { Make a Match }\end{array}$ & \\
\hline $90-100$ & 3 & 18.75 & 2 & 12.5 & Sangat Baik \\
$75-89$ & 3 & 18.75 & 2 & 12.5 & Baik \\
$60-74$ & 6 & 37.5 & 8 & 50 & Cukup \\
$<60$ & 4 & 25 & 4 & 25 & Gagal \\
Jumlah & 16 & 100 & 16 & 100 & - \\
\hline
\end{tabular}

Pada Tabel 2 di atas dapat menunjukan bahwa pada kelas TGT terdapat 3 siswa (18.7\%) yang berada pada kualifikasi sangat baik, 3 siswa (18.75\%) berada pada kualifikasi baik, 6 siswa (37.5\%) berada pada kualifikasi cukup dan 4 siswa $(25 \%)$ berada pada kualifikasi gagal. Sedangkan pada kelas Make a Match terdapat 2 siswa (12.5\%) yang berada pada kualifikasi sangat baik, 2 siswa 
(12.5\%) berada pada kualifikasi baik, 8 siswa (50\%)berada pada kualifikasi cukup dan 4 siswa (25\%) berada pada kualifikasi gagal.

\section{Uji Statistik}

\section{a) Uji Normalitas}

Tabel 3. Uji Normalitas Shapiro Wilk

\begin{tabular}{|c|c|c|c|c|}
\hline \multicolumn{2}{|c|}{ Kelas } & \multicolumn{3}{c|}{ Shapiro Wilk } \\
\cline { 3 - 5 } \multirow{2}{*}{ Nilai } & Kelas TGT & Statistic & Df & Sig \\
\cline { 2 - 5 } & Kelas Make a Match & 0,938 & 16 & 0,327 \\
\hline
\end{tabular}

Berdasarakan data yang diperoleh pada Tabel 3 di atas signifikansi untuk kelas TGT adalah $0,327(>0,05)$ dan kelas Make a Match yaitu 0,064 $(>0,05)$. Dengan demikian maka distribusi data kedua kelas eksperimen dikatakan normal.

b) Uji Varians

Tabel 4. Uji Homogenitas

\begin{tabular}{|c|c|c|c|}
\hline Nilai & df1 & df2 & Sig. \\
\cline { 1 - 1 } Levene Statistic & 1 & 30 & 0,406 \\
\hline 0,710 & 1 & & \\
\hline
\end{tabular}

Berdasarkan data Tabel 4.10 terlihat bahwa nilai signifikansinya adalah $0,406(>0,05)$, ini menunjukkan bahwa data tes akhir kedua kelas mempunyai varian yang sama.

\section{c) Uji T}

Tabel 5. Uji T

\begin{tabular}{|c|c|c|c|}
\hline \multirow{2}{*}{ Kelas } & \multicolumn{3}{|c|}{ T-test for equality of means } \\
\cline { 2 - 4 } & $\mathrm{T}$ & $\mathrm{Df}$ & Sig (2-tiled) \\
\hline $\begin{array}{c}\text { Equal variances } \\
\text { assesmed }\end{array}$ & 1,164 & 30,254 \\
\hline $\begin{array}{c}\text { Equal variances not } \\
\text { assesmed }\end{array}$ & 1,164 & 26,799 & 0,255 \\
\hline
\end{tabular}

Dengan kriterianya:

1. Jika sig < $\alpha(0,05)$, maka terdapat perbedaan hasil belajar pada kelas eksperimen I (menggunakan model pembelajaran TGT) dengan kelas eksperimen II (menggunakan model Make a Match)

2. Jika sig $>\alpha(0,05)$, maka tidak terdapat perbedaan hasil belajar pada kelas eksperimen (menggunakan model pembelajaran TGT) dengan kelas eksperimen II menggunakan model pembelajaran Make a Match). 
Berdasarkan hasil dari Tabel 5 di atas menunjukan bahwa nilai signifikansi yang digunakan adalah Equal variances assesmed yaitu 0,254 (> 0.05) karena data tersebut terdisribusi normal sehingga dapat disimpulkan bahwa tidak terdapat perbedaan hasil belajar antara model pembelajaran kooperatif tipe TGT dan tipe Make a Match. Hal ini dikarenakan penerapan kedua model pembelajaran ini membuat penilaian rata-rata siswa berada pada kualifiasi tuntas. Selain itu, penerapan kedua model pembelajaran ini juga terdapat sedikit kemiripan dalam penerapannya, namun pada kenyataanya model pembelajaran kooperatif tipe TGT memiliki nilai akhir rata-rata yang lebih tinggi dari pada tipe Make a Match. Hal ini dapat dilihat dari nilai rata-rata tes akhir yang diperoleh oleh kedua model pembelajaran.

Untuk kelas TGT nilai rata-rata yang diperoleh dari nilai tes akhir adalah 66.125 sedangkan unutk kelas make a match adalah 57.3125. Hal ini dikarenakan karena pada proses pembelajaran pada kelas TGT siswa lebih fokus dan cenderung bekerja sama untuk memecahkan soal dari pada kelas Make a Match.

\section{KESIMPULAN}

1. Kualifikasi hasil belajar siswa menggunakan model pembelajaran kooperatif tipe Team Games Tournament dari 16 siswa terdapat 12 siswa (75\%) berada pada kualifikasi tuntas dan 4 siswa $(25 \%)$ berada pada kualifikasi gagal, sedangkan pada model pembelajaran kooperatif tipe Make a Match juga memperoleh hal uang sama yang mana terdapat 16 siswa terdapat 12 siswa $(75 \%)$ berada pada kualifikasi tuntas dan 4 siswa (25\%) berada pada kualifikasi gagal. Dengan demikian hal ini menunjukan bahwa kedua model pembelajaran ini dapat membantu siswa untuk memahami materi Konsep Mol.

2. Hasil uji hipotesis, nilai signifikansinya 0.25 (> 0.05), dengan demikian maka $\mathrm{H}_{0}$ diterima sehingga dapat disimpulkan bahwa tidak terdapat perbedaan hasil belajar siswa menggunakan model pembelajaran kooperatif tipe TGT dan tipe Make a Match, yang mana nilai rata-rata untuk kelas yang menggunakan model pembelajaran kooperatif tipe TGT adalah 66,125 sedangkan tipe Make a Match adalah 57,3125 .

\section{DAFTAR PUSTAKA}

Amahoroe, R, A. (2015). Komparasi Penggunaan Media Teka-Teki Silang Dan Chemopoly Terhadap Hasil Belajar Siswa Pada Konsep Hidrokarbon Kelas X SMA Negeri 5 Ambon. Skripsi. Universitas Pattimura Ambon

Anggraini, P.K., Ashadi., \& Utami, B. (2015). Studi Komparasi Pembelajaran Kooperative Metode Team Games Tournament (TGT) dan Team Assissted Individuallized (TAI) Pada Sub Pokok Bahasan Konsep Mol Di SMA Negeri 1 Sukoharjo Tahun 2013/2014. FPMIPAUNS. Jurnal Pendidikan Kimia (JPK) Vol. 4 No. 1, 211-217.

Aunurrahman. 2004. Belajar dan Pembelajaran. Bandung: Alfabeta

Astrissi G. A. S. O. D., Sukardjo, JS., \& Hastuti, B. (2014). Efektifitas Model Pembelajaran Teams Games Tournament (TGT) Disertai Media Teka-Teki Silang Terhadap Prestasi Belajar Pada Materi Minyak Bumi Siswa Kelas X SMA Negeri 3 Sukoharjo Tahun Pembelajaran 2012/2013. FPMIPA-UNS. Jurnal Pendidikan Kimia (JPK) Vol. 3 No. 2, 22-27

Chang, Raymond. 2005. Kimia Dasar Konsep-Konsep Inti Edisi Ketiga Jilid 1. Jakarta: Erlangga

Dea P.Y., Mulyani, B., \& Utami B. (2016). Studi Komparasi Pembelajaran Make A Match Dan Talking Stick Dengan Memperhatikan Kemampuan Analisis Terhadap Prestasi Belajar Siswa Pada Materi Konsep Mol Kelas X SMA Negeri 5 Surakarta Tahun Pelajaran 2014/2015. FPMIPA-UNS. Jurnal Pendidikan Kimia (JPK) Vol. 5 No. 1, 1-8 
Hamalik. 2009. Kurikulum dan Pembelajaran Cetakan Kesebelas. Jakarta: Bumi Aksara Hamalik. 2011. Kurikulum dan Pembelajaran Cetakan Kesebelas. Jakarta: Bumi Aksara

Lokollo, L. (2013). Perbedaan Hasil Belajar Siswa Kelas X SMA Negeri 12 Ambon Dengan Menggunakan Model Pembelajaran Kooperatif Tipe TGT Dengan Pembelajaran Konvensional Pada Konsep Struktur Atom. Skripsi. Universitas Pattimura. Ambon

Muslich, M. 2009. KTSP Pembelajaran Berbasis Kompetensi dan Kontekstual. Jakarta: Bumia Aksara

Ningtiyas, P \& Siswaya, H. (2012). Penggunaan Metode Kooperatif Tipe TGT Dilengkapi Modul Dan LKS Ditinjau Dari Aktivitas Siswa. IKIP-PGRI Madiun. Jurnal Penelitian Pembelajaran Fisika. Vol. 3 No. 1 51-58

Rahmayanti E., Redjeki, T., \& Saputro, C. N. A. (2015). Penggunaan Metode Pembelajaran Make A Match Untuk Meningkatkan Keaktifan Dan Prestasi Belajar Pada Materi Pokok Hidrokarbon Siswa Kelas X SMA Negeri 1 Ngemplak Boyolali Tahun Pelajaran 2013/2014. FKIP-UNS. Jurnal Pendidikan Kimia (JPK). Vol, 4 No. 1 174-181

Ratumanan, T.G., 2004. Belajar dan Pembelajaran. Surabaya: Unessa University Press

Rohendi, D., Waslaluddin., \& Ayu S. P. (2010). Penerapan Cooperative Learning Tipe Make A Match Untuk Meningkatkan Hasil Belajar Siswa Kelas VII Dalam Pembelajaran Teknologi Informasi dan Komunikasi. FPMIPA-UPI. Jurnal Pendidikan IImu Teknologi dan Informasi. 3(1): $19-22$

Rusman. 2011. Model-model Pembelajaran Mengembangkan Profesionalisme Guru. Edisi Kedua. Jakarta: $\quad$ PT. RajaGrafindo Persada

Sadirman, Raharjo, 2008. Media Pendidikan. Jakarta: Rajawali

Sanjaya, W. 2006. Strategi Pembelajaran Berorientasi Standar Proses Pendidikan. Bandung: Kencana

Slameto. 2001. Evaluasi Pendidikan. Jakarta: PT. Bumi Aksara

Slavin, Robert E. Cooverative Learning Teory, Riset dan Praktik. Penerjemah Nurulita Nasron. 2008. Bandung: Nusa Media

Sudijono, A. (2005). Dasar-dasar statistic pendidikan. Edisi 1. Jakarata: Rajawali Pers.

Sugiyono. 2012. Metode Penelitian Kuantitatif Kualitatif Dan R \& D. Bandung: Alfabeta

Sulistyaningsih, F., Mulyani, S. \& Utomo, B.S. (2014). Penerapan Model Pembelajaran Make A Match Berbantuan Power Point Dilengkapi LKS Untuk Meningkatkan Motivasi Dan Hasil Belajar Pada Pokok Bahasan Isomer Dan Reaksi Senyawa Hidrokarbon Kelas X SMA Batik 1 Surakarta Tahun Pelajaran 2012/2013. FPMIPA-UNS. Jurnal Pendidikan Kimia (JPK) Vol. 3 No. 2, 82-87

Susilo, J.M, 2006. Kurikulum Tingkat Satuan Pendidikan. Jakarta: Pustaka Belajar

Trianto. 2007. Model-model Pembelajaran Inovatif Berorientasi Konstruktivistik. Jakarta: Prestasi Pustaka

Trihendradi, Corelius. 2004. Memecahkan Kasus Statistik: Deskriptif, Parametrik dan non-parametrik dengan SPSS 12. Yogyakarta: ANDI

Yamin, Mohammad. 2009. Manajemen Mutu Kurikulum Pendidikan Panduan Menciptakan Manajemen Mutu Pendidikan Berbasis Kurikulum yang progresif dan Inspiratif. Jogjakarta: Diva Pres 